\title{
Gyroscope and Accelerometer Sensor on the Lanange Jagad Dance Robot Balance System
}

\section{Sensor Gyroscope dan Accelerometer pada Sistem Keseimbangan Robot Seni Tari Lanange Jagad}

\author{
Ahmad Sopi Samosir ${ }^{1}$, Nuryono Satya Widodo ${ }^{2}$ \\ ${ }^{1}$ Mahasiswa Program Studi Teknik Elektro, Universitas Ahmad Dahlan, Indonesia \\ ${ }^{2}$ Dosen Program Studi Teknik Elektro, Universitas Ahmad Dahlan, Indonesia
}

\section{INFORMASI ARTIKEL}

\section{Riwayat Artikel:}

Dikirimka 05 Agustus 2019, Direvisi 19 Agustus 2019,

Diterima 17 Juli 2020.

\section{Kata Kunci: \\ Robot Humanoid, \\ Accelerometer, \\ Gyroscope, \\ Kalman Filter, \\ KRSTI.}

\section{Penulis Korespondensi:}

Ahmad Sopi Samosir, Program Studi Teknik Elektro, Universitas Ahmad Dahlan, Kampus 4 Universitas Ahmad Dahlan, Jln. Ring Road Selatan, Tamanan, Banguntapan, D.I. Yogyakarta, Indonesia.

Surel:

ahmadsopi236@gmail.com

\begin{abstract}
ABSTRAK
In performing dance moves, humanoid robots are expected to move flexibly and not easily fall during dance moves. To reduce the risk of robots falling while performing dance moves, a balance control system using a gyroscope sensor and accelerometer from the MPU6050 is controlled through the Arduino MEGA 2560 PRO. Robots that have balance control, are able to maintain stability in track conditions that have a certain degree of slope. This balance control system uses the Kalman filter method for processing data from the gyroscope sensor and accelerometer in order to reduce the noise that occurs during the robot's balance process. From the results of the test, the percentage of the success rate of robots in rest was $88.8 \%$, the percentage of success when the robot was running was $86.6 \%$, and the percentage of success when the robot was walking with dancing was $75 \%$. From the results of all tests, humanoid robot has a percentage of $83.4 \%$ after adding a balance control system and when the humanoid robot does not use balance control will only produce a percentage of success rate of $48.4 \%$.
\end{abstract}

Dalam melakukan gerakan tarian, robot humanoid diharapkan dapat bergerak secara luwes dan tidak mudah terjatuh pada saat melakukan gerakan tarian. Untuk mengurangi risiko robot terjatuh saat melakukan gerakan tarian, digunakan suatu sistem kendali keseimbangan dengan menggunakan sensor gyroscope dan accelerometer dari MPU6050 yang dikontrol melalui Arduino MEGA 2560 PRO. Robot yang memiliki kendali keseimbangan, mampu menjaga stabilitas pada kondisi lintasan yang mempunyai tingkat kemiringan tertentu. Sistem kendali keseimbangan ini menggunakan metode kalman filter untuk proses pengolahan data dari sensor gyroscope dan accelerometer agar dapat mengurangi noise yang terjadi saat proses keseimbangan pada robot. Dari hasil pengujiannya, persentase tingkat keberhasilan robot dalam kondisi diam sebesar $88,8 \%$, persentase keberhasilan ketika robot dalam kondisi berjalan adalah $86,6 \%$, dan persentase keberhasilan ketika robot dalam kondisi berjalan dengan menari adalah $75 \%$. Dari hasil seluruh pengujian, robot humanoid memiliki hasil persentase sebesar $83,4 \%$ setelah ditambahkan sistem kendali keseimbangan dan saat robot humanoid tidak menggunakan kendali keseimbangan hanya akan menghasilkan persentase tingkat keberhasilan sebesar $48,4 \%$.

This work is licensed under a Creative Commons Attribution-Share Alike 4.0

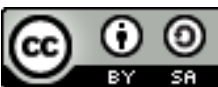

\section{Sitasi Dokumen ini:}

A. S. Samosir and N. S. Widodo, "Gyroscope and Accelerometer Sensor on the Lanange Jagad Dance Robot Balance System," Buletin Ilmiah Sarjana Teknik Elektro, vol. 2, no. 2, pp. 51-58, 2020. DOI: $\underline{10.12928 / \text { biste.v2i2.922 }}$ 


\section{PENDAHULUAN}

Perkembangan Teknologi robotika dapat meningkatkan produktivitas suatu pekerjaan. Dengan adanya robotika, pekerjaan yang sebelumnya sulit dan berbahaya untuk dikerjakan sekarang sudah dapat dikerjakan lebih mudah dan aman [1]. Penelitian pada bidang robotika pun terbilang semakin banyak, tentunya hal ini bukan tanpa tujuan. Demikian penelitian robot khususnya pada robot humanoid, robot humanoid dapat melakukan berbagai aktivitas manusia seperti dalam pengamanan, olahraga, maupun bidang kesenian [2] [3]. Robot humanoid adalah robot berbentuk manusia yang sepenuhnya didesain sebagaimana manusia, cara berjalan, bergerak, dan lain-lain didesain menyerupai manusia yang memiliki tubuh dengan kepala, dua tangan, dan dua kaki [4] [5].

Kontes Robot Seni tari Indonesia (KRSTI) merupakan ajang kompetisi perancangan robot khususnya pada robot humanoid yang memiliki kemampuan yang dapat melakukan gerakan tarian [6]. Pada perlombaan KRSTI, terdapat 2 buah robot yang berada dalam satu arena pertandingan yang melakukan gerakan tarian [7]. Di arena pertandingan KRSTI, robot diharapkan dapat menjaga keseimbangan agar pada saat melakukan gerakan tarian robot tidak mengalami terjadinya terjatuh. Mengingat terkadang kondisi arena yang permukaannya tidak rata atau miring dapat mengganggu kinerja robot dalam melakukan gerakan tarian. Untuk itu robot harus memiliki kemampuan kendali keseimbangan agar dapat seimbang saat melakukan gerakan tarian.

Penerapan keseimbangan pada robot saat ini sudah banyak dilakukan. Salah satunya, penelitian yang dilakukan Masaki Kumagi dan Taka Ochiai tentang "Development of a Robot Balancing on a Ball" yang dilakukan pada tahun 2008. Pada robot ini menggunakan sebuah bola untuk proses keseimbangan robot [8]. Dalam proses kendali keseimbangan, sensor gyroscope dan accelerometer dapat digunakan sebagai data acuan dari sudut kemiringan sebuah kendali keseimbangan seperti yang telah dilakukan di beberapa penelitian [9] [10] [11].

Pada penelitian ini, kendali keseimbangan menggunakan sensor gyroscope dan accelerometer akan diterapkan pada robot humanoid KRSTI. Dengan menggunakan Board Arduino MEGA 2560 PRO sebagai mikrokontroller.

\section{METODE PENELITIAN}

\subsection{Implementasi Hardware}

. Pengimplementasian perangkat keras kendali keimbangan robot humanoid KRSTI dapat dilihat pada diagram blok sistem Gambar 1. Kendali keseimbangan pada penelitian ini menggunakan Board Arduino MEGA 2560 PRO sebagai kontroler utama pada sistem [12]. Board Arduino MEGA 2560 PRO adalah board mikrokontroller yang menggunakan chipset atmel ATmega2560 dan chip USB-UART CH340G sebagai saluran komunikasi data. Board Arduino MEGA 2560 PRO memiliki clock sebesar $16 \mathrm{MHz}$ dan dapat beroperasi pada tegangan inputan 6V-9V DC yang diberikan langsung pada konektor mikro USB atau melalaui port Vin.

OpenCM 9.04 digunakan sebagai subkontroller yang menghubungkan komunikasi kontroller utama dengan motor servo dynamixel. Mikrokontroller OpenCM 9.04 merupakan keluaran dari perusahaan Robotis yang menggunakan chipset ARM Cortex-M3 32bit dan bersifat opensource, dan menggunakan interface TTL untuk sistem komunikasi dengan servo dynamixel, 6 buah tombol, beberapa port I/O, serta sensor-sensor lainnya.

Sensor gyroscope dan accselerometer digunakan untuk membantu menjaga keseimbangan dari robot yang digunakan. Sensor gyroscope dan accselerometer 3 axis MPU-6050, mengombinasikan gyroscope 3 axis dan accelerometer 3 axis dalam sebuah chip yang terintegrasi dengan Digital Motion Processor ${ }^{\mathrm{TM}}\left(D^{\mathrm{M}} \mathrm{P}^{\mathrm{TM}}\right)$ yang memproses suatu algoritme penentuan gerak 6 axis yang kompleks. Sensor MPU-6050 menggunakan interface I2C untuk komunikasi data dengan mikrokontroller [13].

Robot humanoid KRSTI menggunakan 23 motor servo dynamixel. Diantaranya menggunakan tipe dynamixel MX-54, dynamixel MX-28, dynamixel $A X-12$, dan dynamixel XL-320. Motor servo dynamixel adalah aktuator yang memiliki high performance dengan menggunakan Motor DC (Direct Current) + Direction Gearhead + Controller + Driver + Network, dalam satu modul aktuator. Dapat diprogram dan networkable, status aktuator dapat dibaca dan dipantau melalui aliran saluran data.

Catu Daya atau sering disebut dengan Power Supply adalah sebuah piranti yang berguna sebagai sumber listrik untuk piranti lainnya. Untuk dapat mengoperasikan robot, dibutuh catu daya yang akan memberi tegangan input ke mikrokontroller maupun motor servo. Robot KRSTI membutuhkan catu daya yang cukup besar karena harus mampu bertahan lama menggerakkan 23 motor servo sesuai dengan lamanya durasi waktu pertandingan, sumber tegangan yang digunakan yaitu baterai lithium-polymer tiga cell dengan tegangan DC 12 volt dan arus $2600 \mathrm{mAh}$ yang akan didistribusikan menjadi beberapa variasi tegangan 


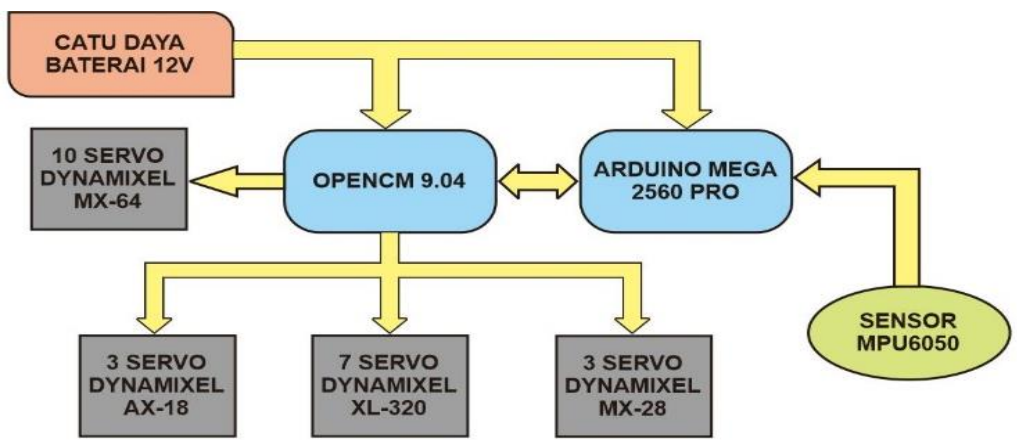

Gambar 1. Diagram blok sistem

\subsection{Implementasi Software}

\subsubsection{Kalman Filter}

Secara umum kalman filter adalah algoritma filter kompleks yang mengambil hasil pengukuran yang masih memiliki noise statistik dan ketidak pastian dari waktu ke waktu, dan menghasilkan estimasi status objek yang lebih dapat diandalkan daripada pengukuran tunggal. Kalman filter memiliki dua langkah (Gambar 2), yaitu memperbaharui dan memprediksi [14] [15] [16].

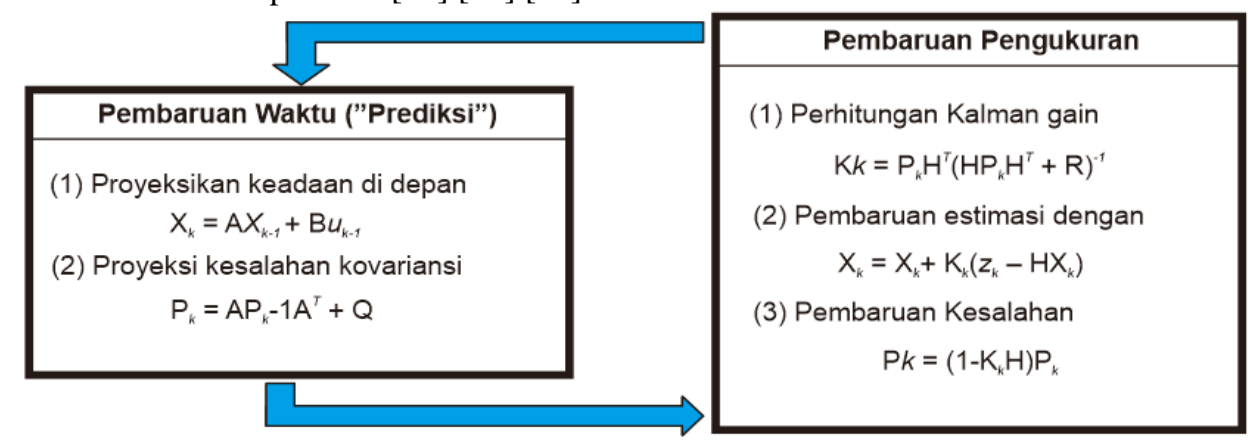

Gambar 2. Persamaan perbaharui dan prediksi kalman filter

Keuntungan kalman filter adalah bobot relatif yang diberikan untuk pengukuran dan perkiraan keadaan saat ini, dan dapat "diatur" untuk mencapai kinerja tertentu [17]. Dengan gain yang tinggi, filter menempatkan lebih banyak beban pada pengukuran terbaru, dan dengan demikian mengikuti mereka lebih responsif. Dengan gain rendah, filter mengikuti prediksi model lebih dekat. Pada ekstrem, keuntungan tinggi yang dekat dengan satu akan menghasilkan lintasan yang diperkirakan lebih lonjakan, sementara keuntungan rendah mendekati nol akan memuluskan kebisingan tetapi menurunkan respons. Dalam proses keseimbangan (Gambar 3), data yang diperoleh dari nilai gyroscope dan accelerometer akan dilakukan penyaringan nilai data menggunakan Kalman filter agar proses sistem kendali keseimbangan lebih stabil.

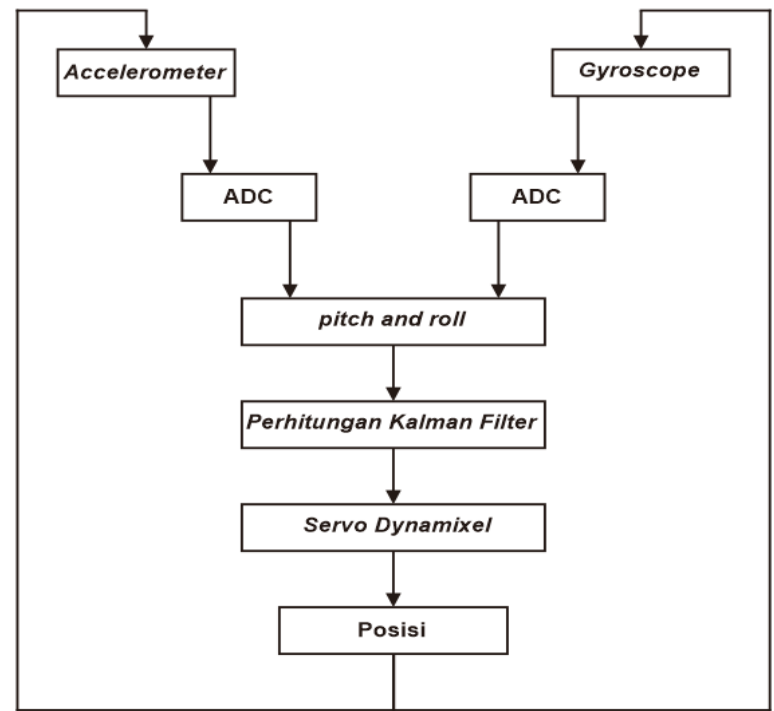

Gambar 3. Diagram blok sistem proses keseimbangan 


\subsubsection{Flowchart Sistem Kendali Keseimbangan}

Proses kendali Keseimbangan robot humanoid KRSTI memiliki tahapan proses inisialisasi hardware hingga proses eksekusi keseimbangan. Tahapan proses kendali keseimbangan dapat digambarkan melalui flowchart sistem (Gambar 4).

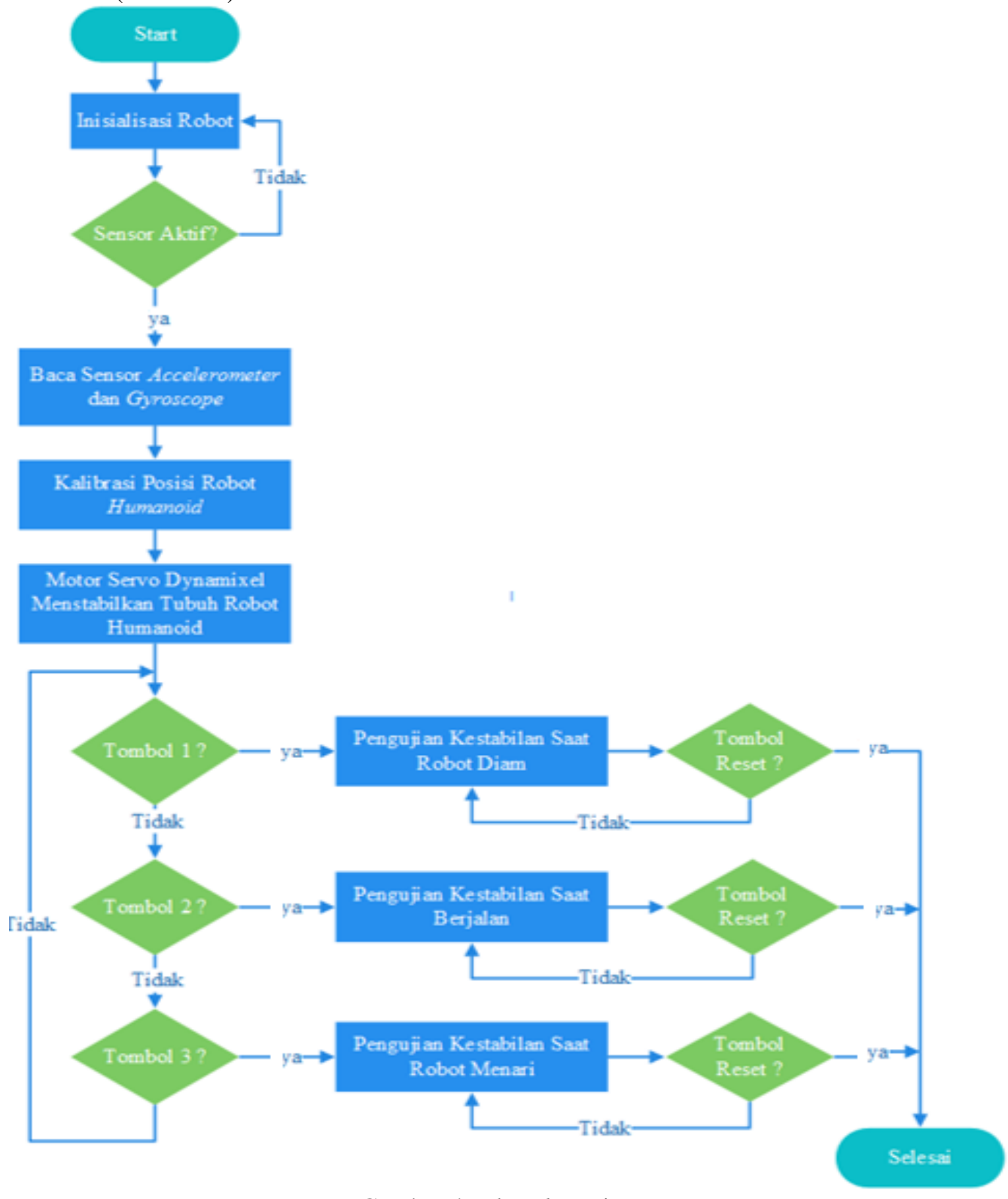

Gambar 4. Flowchart sistem

Pada flowchart sistem (Gambar 4) ketika robot dinyalakan dan start maka robot akan melakukan inisialisasi program. Setelah inisialisasi selesai maka sistem akan membaca sensor gyroscope dan accelerometer. Jika nilai sensor sudah terbaca, proses selanjutnya adalah robot akan melakukan proses kalibrasi posisi. Kalibrasi posisi ini dilakukan untuk menyesuaikan posisi robot dengan bidang track arena yang digunakan sehingga robot akan menyesuaikan dengan nilai awal dari sensor accelerometer dan gyroscope yang telah ditentukan. Ketika proses kalibrasi, motor servo dynamixel pada bagian kaki robot akan bergerak menstabilkan badan robot. Robot yang sudah seimbang ditandai dengan robot diam ketika sudah berhasil memposisikan diri terhadap bidang track arena.

Setelah itu terdapat beberapa tombol pada robot yang berfungsi sebagai pemberi instruksi pada robot. Fungsi tombol yang ada adalah tombol 1 yaitu untuk kestabilan robot pada saat diam, tombol 2 untuk menginstruksikan robot melakukan kestabilan saat berjalan dan tombol 3 untuk menginstruksikan robot melakukan kestabilan saat berjalan dan menari. Program masing-masing fungsi tombol akan melakukan proses looping sebelum tombol reset ditekan yang menandakan program yang dijalankan telah selesai. 


\section{HASIL DAN PEMBAHASAN}

Proses pengujian dilakukan dengan menggunakan 3 keadaan yaitu pada saat robot diam di tempat, saat berjalan, dan saat berjalan dengan menari.

\subsection{Pengujian Keseimbangan Robot KRSTI Saat Kondisi Diam}

Pengujian ini dilakukan dengan cara memberikan sudut kemiringan pada bidang lintasan sebesar $0^{\circ}$ sampai dengan $10^{\circ}$ dan setiap sudut kemiringan dilakukan pengambilan data sebanyak 6 kali percobaan (Gambar 5). Hasil dari keseluruhan pengujian saat robot dalam keadaan diam akan dilakukan proses rata-rata (Tabel 1) agar dapat mengetahui persentase tingkat keberhasilan saat robot dalam keadaan diam.

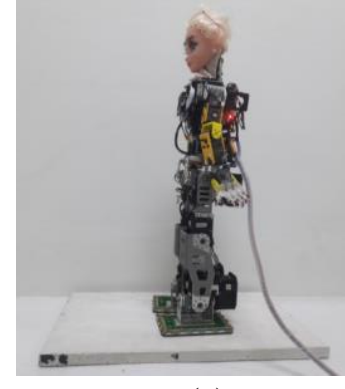

(a)

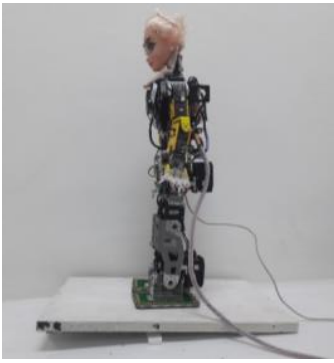

(d)

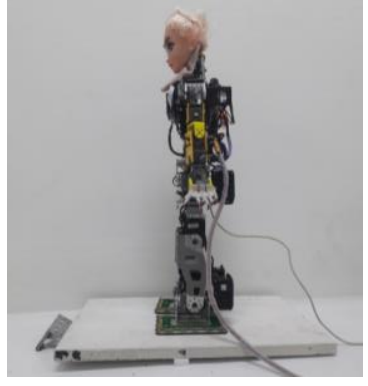

(b)

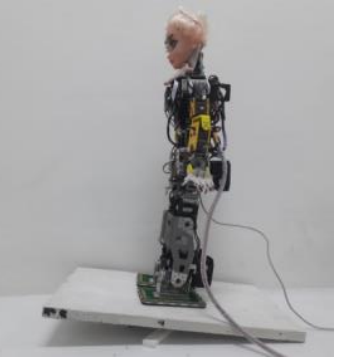

(e)

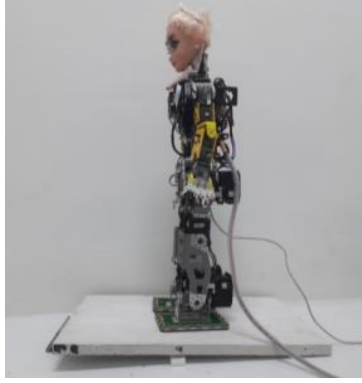

(c)

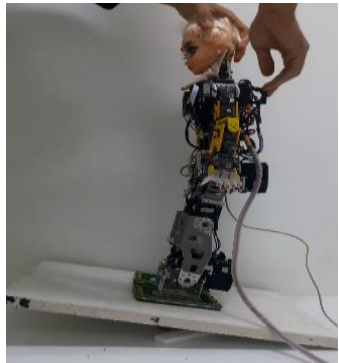

(f)

Gambar 5. Pengujian robot dalam keadaan diam, (a) Sudut kemiringan $0^{\circ}$, (b) Sudut kemiringan $2^{\circ}$, (c) Sudut kemiringan $4^{\circ}$, (d) Sudut kemiringan $6^{\circ}$, (e) Sudut kemiringan $8^{\circ}$, (f) Sudut kemiringan $10^{\circ}$

Tabel 1. Hasil rata-rata persentase tingkat keberhasilan pengujian robot dalam keadaan diam

\begin{tabular}{ccc}
\hline Kemiringan Track (derajat) & \multicolumn{2}{c}{ Persentase Keberhasilan (\%) } \\
\cline { 2 - 3 } & Dengan Sistem Keseimbangan & Tanpa sistem keseimbangan \\
\hline 0 & 100 & 100 \\
2 & 100 & 100 \\
4 & 100 & 66,6 \\
6 & 100 & 16,6 \\
8 & 100 & 0 \\
10 & 33,3 & 0 \\
\hline Rata-rata & 88,8 & 47,2 \\
\hline
\end{tabular}

Dari nilai rata-rata persentase tingkat keberhasilan pengujian robot setelah dan sebelum ditambahkan sensor accelerometer dan gyroscope, pada posisi robot dalam keadaan diam serta diberikan kemiringan bidang track $0^{\circ}$ sampai $10^{\circ}$ adalah sebesar $88,8 \%$ dan $47,2 \%$. Dari hasil perbandingan nilai rata-rata, dapat disimpulkan bahwa setelah robot ditambahkan sensor accelerometer dan gyroscope dapat membantu untuk menjaga keseimbangan dan kestabilan robot dalam kondisi track dengan kemiringan hingga $10^{\circ}$.

\subsection{Pengujian Keseimbangan Robot KRSTI Saat Kondisi Berjalan}

Pengujian ini dilakukan dengan cara memberikan sudut kemiringan pada bidang track sebesar $0^{\circ}$ sampai dengan $8^{\circ}$ dan setiap sudut kemiringan dilakukan pengambilan data sebanyak 6 kali percobaan (Gambar 6). Hasil dari keseluruhan pengujian saat robot dalam keadaan berjalan akan dilakukan proses rata-rata (Tabel 2) agar dapat mengetahui persentase tingkat keberhasilan saat robot dalam keadaan berjalan.

Dari data pada Tabel 2 nilai rata-rata persentase tingkat keberhasilan pengujian robot setelah dan sebelum ditambahkan sensor accelerometer dan gyroscope pada posisi robot dalam keadaan berjalan serta diberikan 
kemiringan bidang track $0^{\circ}$ sampai $8^{\circ}$ adalah sebesar $86,6 \%$ dan $56,6 \%$. Dari hasil perbandingan nilai rata-rata pada Tabel 2 dapat disimpulkan bahwa setelah robot ditambahkan sensor accelerometer dan gyroscope dapat membantu untuk menjaga keseimbangan dan kestabilan robot dalam kondisi track dengan kemiringan hingga $8^{\circ}$.

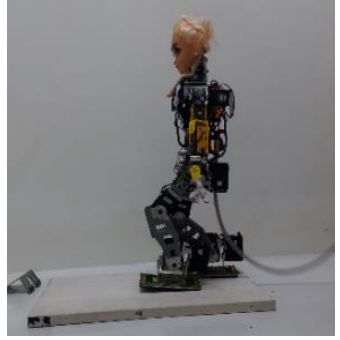

(a)

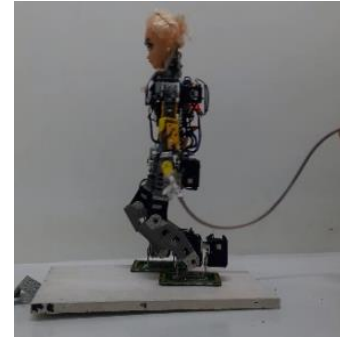

(b)

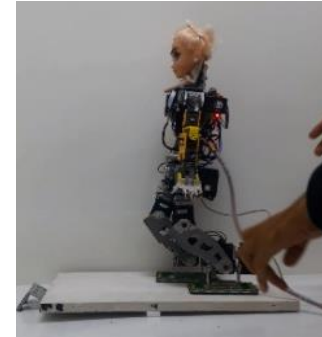

(c)

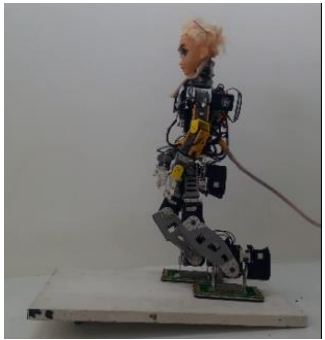

(d)

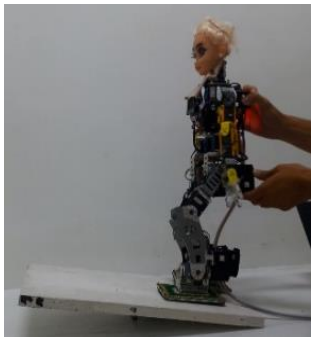

(e)

Gambar 6. Pengujian robot dalam keadaan berjalan, (a) Sudut kemiringan $0^{\circ}$, (b) Sudut kemiringan $2^{\circ}$, (c) Sudut kemiringan $4^{\circ}$, (d) Sudut kemiringan $6^{\circ}$, (e) Sudut kemiringan $8^{\circ}$

Tabel 2. Hasil rata-rata persentase tingkat keberhasilan pengujian robot dalam keadaan berjalan

\begin{tabular}{ccc}
\hline Kemiringan Track (derajat) & \multicolumn{2}{c}{ Persentase Keberhasilan (\%) } \\
\cline { 2 - 3 } & Dengan Sistem Keseimbangan & Tanpa sistem keseimbangan \\
\hline 0 & 100 & 100 \\
2 & 100 & 100 \\
4 & 100 & 66,6 \\
6 & 100 & 16,6 \\
8 & 33,3 & 0 \\
\hline Rata-rata & 86,6 & 56,6 \\
\hline
\end{tabular}

\subsection{Pengujian Keseimbangan Robot KRSTI Saat Kondisi Berjalan dan Menari}

Pengujian ini dilakukan dengan cara memberikan sudut kemiringan pada bidang track sebesar $0^{\circ}$ dan $4^{\circ}$. Dan setiap sudut kemiringan dilakukan pengambilan data sebanyak 6 kali percobaan (Gambar 7). Hasil dari keseluruhan pengujian saat robot dalam keadaan berjalan dan menari akan dilakukan proses rata-rata (Tabel 3) agar dapat mengetahui persentase tingkat keberhasilan saat robot dalam keadaan berjalan.

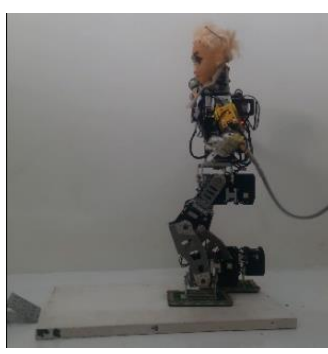

(a)

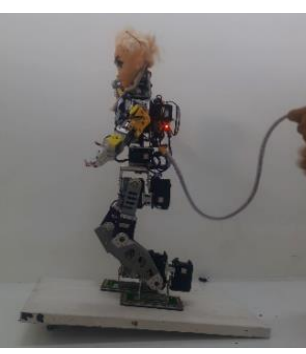

(b)

Gambar 7. Pengujian robot dalam keadaan berjalan dan menari , (a) Sudut kemiringan $0^{\circ}$, (b) Sudut kemiringan $4^{\circ}$

Dari data nilai rata-rata persentase tingkat keberhasilan pengujian robot setelah dan sebelum ditambahkan sensor accelerometer dan gyroscope, pada posisi robot dalam keadaan berjalan disertai menari dan diberikan 
kemiringan bidang track $0^{\circ}$ dan $4^{\circ}$ adalah sebesar $75 \%$ dan $41,6 \%$. Dari hasil perbandingan nilai rata-rata pada, dapat disimpulkan bahwa setelah robot ditambahkan sensor accelerometer dan gyroscope dapat membantu untuk menjaga keseimbangan dan kestabilan robot dalam kondisi track dengan kemiringan hingga $4^{\circ}$.

Tabel 3. Hasil rata-rata persentase tingkat keberhasilan pengujian robot dalam keadaan berjalan dan menari Kemiringan Track (derajat) Persentase Keberhasilan (\%)

\begin{tabular}{ccc} 
& Dengan Sistem Keseimbangan & Tanpa sistem keseimbangan \\
\hline 0 & 100 & 83,3 \\
4 & 50 & 0 \\
\hline Rata-rata & 75 & 41,6 \\
\hline
\end{tabular}

Dari keseluruhan pengujian terhadap semua kondisi track, didapat persentase hasil rata-rata tingkat keberhasilan menggunakan sistem keseimbangan sebesar 83,4\% sedangkan untuk tingkat keberhasilan tanpa menggunakan sistem keseimbangan sebesar $48,4 \%$. Hasil persentase seluruh pengujian dapat dilihat pada Tabel 4 .

Tabel 4. Hasil rata-rata persentase tingkat keberhasilan keseluruhan pengujian robot

\begin{tabular}{ccc}
\hline \multirow{2}{*}{ Kondisi Pengujian Robot } & \multicolumn{2}{c}{ Persentase Keberhasilan (\%) } \\
\cline { 2 - 3 } & Dengan Sistem Keseimbangan & Tanpa sistem keseimbangan \\
\hline Diam & 88,8 & 47,2 \\
Berjalan & 86,6 & 56,6 \\
Menari & 75 & 41,6 \\
\hline Rata-rata & 83,4 & 48,4 \\
\hline
\end{tabular}

\section{KESIMPULAN}

Dari penelitian dan perancangan sistem yang telah direalisasikan dapat disimpulkan hasil pengujian keseluruhan robot humanoid setelah ditambah sistem keseimbangan didapatkan persentase tingkat keberhasilan pada kondisi diam sebesar $88,8 \%$, pada kondisi berjalan sebesar 86,6\% dan pada kondisi menari sebesar $75 \%$ dengan rata-rata tingkat keberhasilan dari semua kondisi sebesar 83,4\%, dengan demikian dapat disimpulkan bahwa robot dapat menjaga keseimbangan dan kestabilan.

\section{UCAPAN TERIMA KASIH}

Penulis mengucapkan terima kasih yang sebesar-besar kepada editor, reviewer dan semua pihak yang telah mendukung penelitian ini atas segala saran, masukan dan telah membantu dalam proses penerbitan naskah. Ucapan terima kasih juga kepada BIMAWA yang telah mendukung penelitian dan memberikan bantuan moral dan material.

\section{REFERENSI}

[1] J. Pembangunan, P. : Fondasi, D. Aplikasi, M. Ngafifi, S. Negeri, and S. Wonosobo, "Kemajuan Teknologi dan Pola Hidup Manusia dalam Persperktif Sosial Bidaya," Jurnal Pembangunan Pendidikan: Fondasi dan Aplikasi, vol. 2, no. 1, pp. 33-45, Jun. 2014.

[2] A. I. Bardani and N. S. Widodo, "Deteksi Zona pada KRSTI dengan Sensor Warna TCS3200," Buletin Ilmiah Sarjana Teknik Elektro, vol. 1, no. 2, p. 56, 2019.

[3] S. Al Irfan and N. S. Widodo, "Application of Deep Learning Convolution Neural Network Method on KRSBI Humanoid R-SCUAD Robot,” Buletin Ilmiah Sarjana Teknik Elektro, vol. 2, no. 1, pp. 40-50, 2020.

[4] I. Maulana and N. S. Widodo, "Sistem Pengolah Musik Sebagai Kontrol Gerak Robot Humanoid," Buletin Ilmiah Sarjana Teknik Elektro, vol. 1, no. 2, p. 46, 2019.

[5] S. Kajita, H. Hirukawa, K. Harada, and K. Yokoi, "Introduction to Humanoid Robotics," in Introduction to Humanoid Robot, vol. 101, Springer Verlag, 2014.

[6] R. Zahra, Thamrin, and P. Jaya, "Rancang Bangun Robot Humanoid Penari Gending Sriwijaya Menggunakan Modul EasyVR3," Voteknika: Jurnal Teknik Elektronika dan Informatika, vol. 5, no. 2, pp. 129-137.

[7] U. W. Putri and Thamrin, "Perancangan Pergerakan Kaki Robot Humanoid Menggunakan Servo Dynamixel OpenCM9.04," Voteknika: Jurnal Teknik Elektronika dan Informatika, vol. 7, no. 3, pp. 76-84.

[8] M. Kumagai and T. Ochiai, "Development of a robot balancing on a ball," in 2008 International Conference on Control, Automation and Systems, ICCAS 2008, 2008, pp. 433-438.

[9] M. Ismail, R. A. Dziyauddin, and N. A. A. Salleh, "Performance evaluation of wireless accelerometer sensor for water pipeline leakage," 2016, pp. 120-125.

[10] A. Maarif, R. D. Puriyanto, and F. R. T. Hasan, "Robot Keseimbangan dengan Kendali PID dan Kalman Filter," IT JOURNAL RESEARCH AND DEVELOPMENT, vol. 4, no. 2, Feb. 2020.

[11] Z. Liang, H. Zhao, and Y. Hao, "An omnidirectional walk for a biped robot based on gyroscope-accelerometer measurement," in 2014 IEEE International Conference on Mechatronics and Automation, IEEE ICMA 2014, 2014, pp. 1052-1057. 
[12] A. S. Ilmi and M. Muslihudin, "Sistem Klasifikasi Otomatis Volume Balok dengan Arduino," Buletin Ilmiah Sarjana Teknik Elektro, vol. 1, no. 1, p. 9, 2019.

[13] K. Kunal, A. Z. Arfianto, J. E. Poetro, F. Waseel, and R. A. Atmoko, "Accelerometer Implementation as Feedback on 5 Degree of Freedom Arm Robot," Journal of Robotics and Control (JRC), vol. 1, no. 1, pp. 31-34, 2020.

[14] A. Ma'arif, I. Iswanto, A. A. Nuryono, and R. I. Alfian, "Kalman Filter for Noise Reducer on Sensor Readings," Signal and Image Processing Letters, vol. 1, no. 2, pp. 11-22, Jul. 2019.

[15] S. Yuliani and H. M. Saputra, "Kolaborasi Kalman Filter dengan Complementary Filter untuk Mengoptimasi Hasil Sensor Gyroscope dan Accelerometer Reengineering Software Data Logger Triaxial Digital View project Modified Fourth-Order Runge-Kutta Method Based on Trapezoid Approach View pro," in Prosiding Seminar Nasional Rekayasa dan Desain Itenas, 2016, pp. 63-68.

[16] G. Welch and G. Bishop, "An Introduction to the Kalman Filter," 1995.

[17] M. S. Grewal and A. P. Andrews, Kalman Filtering: Theory and Practice with MATLAB. Wiley, 2015.

\section{BIOGRAFI PENULIS}

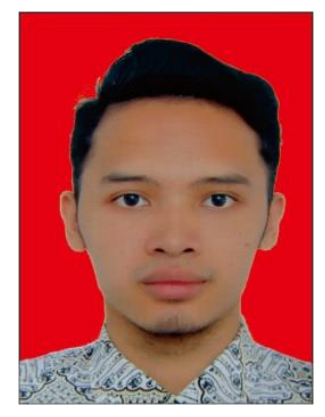

Ahmad Sopi Samosir adalah mahasiswa di Universitas Ahmad Dahlan. Dia adalah mahasiswa S1 Program Studi Teknik Elektro Universitas Ahmad Dahlan sejak tahun 2015 dan berkonsentrasi dibidang Otomasi Industri

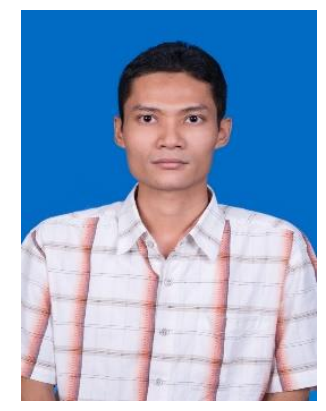

Nuryono Satya Widodo, S.T., M.Eng. adalah dosen di Universitas Ahmad Dahlan. Beliau lulusan S2 Universitas Gadjah Mada (UGM) Indonesia tahun 2010. Konsentrasi Beliau adalah Sistem Isyarat Elektronis 